\title{
An evaluation of surface micro- and mesoplastic pollution in pelagic ecosystems of the Western Mediterranean Sea
}

\author{
Faur Florian ${ }^{1,2}$, Saini Camille ${ }^{1}$, Potter Gael ${ }^{1}$, Galgani Francois ${ }^{3}$, De Alencastro Luiz Felippe ${ }^{2}$, \\ Hagmann Pascal ${ }^{1, *}$ \\ ${ }^{1}$ Oceaneye Assoc, $\mathrm{CH}-1201$ Geneva, Switzerland. \\ ${ }^{2}$ Ecole Polytech Fed Lausanne, Cent Environm Lab, EPFL ENAC IIE GR CEL, CH-1015 Lausanne, \\ ${ }^{3}$ IFREMER, F-20600 Bastia, France.
} Switzerland.

* Corresponding author : Pascal Hagmann, email address : pascal.hagmann@oceaneye.ch

\begin{abstract}
:
This study examines the distribution, abundance and characteristics of surface micro- and mesoplastic debris in the Western Mediterranean Sea. 41 samples were collected in 2011 (summer) and 2012 (summer). Results, firstly, revealed that micro- $(<5 \mathrm{~mm})$ and mesoplastic debris were widely and uniformly distributed in this area with average concentrations of 130,000 parts $/ \mathrm{km}(2)$ and 5700 parts $/ \mathrm{km}(2)$, respectively. Importantly, a strong correlation between micro- and mesoplastic concentrations was identified. Secondly, a classification based on the shape and appearance of microplastics indicated the predominant presence of fragments $(73 \%)$ followed by thin films (14\%). Thirdly, the average mass ratio of microplastic to dry organic matter has been measured at 0.5 , revealing a significant presence of microplastics in comparison to plankton. Finally, a correction method was applied in order to correct wind mixing effect on microplastics' vertical distribution. This data allows for a comprehensive view, for the first time, of the spatial distribution and nature of plastic debris in the Western Mediterranean Sea.
\end{abstract}

Keywords : Plastic debris, Marine pollution, Mediterranean Sea, Surface net tow, Microplastic pollution, Neustonic plastic 


\section{Introduction}

For decades, humans have been disposing plastic waste in the sea and rivers, causing coastline, seabed and sea surface pollution. World plastic production was estimated in 2011 at 280 million tons (PlasticsEurope, 2012) and the increasing level of consumption is coupled with the growth of plastic waste in the marine environment via littering, industrial discharge, terrestrial runoff (Thompson et al., 2004). Most of these polymers are highly persistent in the marine environment, with degradation estimated to take from decades to millennia to complete (Andrady, 2011). The major part of floating marine debris is constituted of high production volume polymers such as polyethylene, polypropylene and foams which have lower densities than sea water. Plastic at sea undergo fragmentation, leading to the formation of plastic particles known as "microplastics". Due to the buoyant and persistent properties of many plastics, microplastics have the potential to become widely dispersed in the marine environment via wind and geostrophic, Ekman and Stokes currents.

Several harmful effects of plastic wastes on marine ecosystems have been pointed out. These effects can be divided in two broad categories. First, plastics as solid non-degradable particles can cause severe damages to large marine fauna through ingestion or entanglement, sometimes leading to death (Boerger et al., 2010; Derraik, 2002; Moser and Lee, 1992; van Franeker et al., 2011). Plastics ingestion may also affect lower trophic levels like worms and barnacles (Browne et al., 2008; Thompson et al., 2004; von Moos et al., 2012). It should be noted that a proportion of marine plastic debris have been observed on the seabed (Woodall et al., 2014) and, there, may cause important damage to large marine habitats such as coral reefs (Donohue et al., 2001). Floating debris, on the other hand, may contribute to the dissemination of invasive species (Barnes, 2002). Second, plastic particles may have harmful chemical effects on marine organisms' health. Indeed, chemicals additives of plastics (e.g. phthalates) may have toxicological effects or act as endocrine disruptors if ingested. These chemicals may get released into water through exposure to sunlight and leaching where organisms may ingest them (Teuten et al., 2007). Furthermore, the physical nature of plastics makes them potential vectors for adsorbed persistent organic pollutants (POPs) (Bakir et al., 2014; Mato et al., 2001; Ogata et al., 2009; Teuten et al., 2007).

Previous studies have shown plastic accumulation in convergence zones, resulting in regions of high concentration near the centres of subtropical gyres. The spatial distribution of surface microplastics has been analysed, in particular, in the Western North Atlantic Ocean (Law et al., 2010), the Eastern North Pacific Ocean (Moore et al., 2001, Law et al, 2014) and in local regions such as the Northeast Pacific Ocean (Doyle et al., 2011), in Northeast Atlantic Ocean (Lusher et al, 2014), Singapore's coasts (Ng and Obbard, 2006), or the North 
Western Mediterranean Sea (Collignon et al., 2012). Two recent studies proposed a global view of plastic pollution in the world's oceans, demonstrating the ubiquity of this pollution including the Southern Hemisphere and the subtropical convergence zones (Cózar et al., 2014; Eriksen et al., 2014).

As passive particles, microplastics are subject to wind mixing and their vertical distribution is highly sensitive to wind stress (Kukulka et al., 2012). This result suggests that previous studies, using traditional surface measurements, significantly underestimate the surface microplastic concentration. It is thus necessary to reinterpret surface microplastic concentration data including the effect of wind stress.

Although plastic pollution in the Mediterranean Sea can be presumed to be important - given the high population density in surrounding countries and the fact that it is a closed sea - there is, to our knowledge, only one comparable evaluation of surface microplastic pollution (Collignon et al., 2012). Other studies focus either on the interaction of plastic with fauna (Fossi et al., 2012; Tomás et al., 2002), sediments (Vianello et al., 2013), larger objects (Suaria and Aliani, 2014) or focus on a restricted area (Collignon et al., 2014). This paper proposes an analysis of micro- and mesoplastic concentration in an area included between the Gulf of Lion, Corsica, Sardinia, the Balearics and the Eastern coast of Spain. The results are presented according to two methodologies: the traditional surface measurements and the reinterpretation of these results taking into account the effect of wind stress, as per the correction model proposed by Kukulka and others (Kukulka et al., 2012).

\section{Methodology}

\section{Sampling}

The association Oceaneye took 41 surface samples during 2 cruises between August $31^{\text {st }}$ and September $22^{\text {nd }}$ 2011 and between August $5^{\text {th }}$ and August $29^{\text {th }}$ 2012. The samples were taken in an area in the Mediterranean Sea between $38-44^{\circ} \mathrm{N}$ and $001-010^{\circ} \mathrm{E}$ (between Gulf of Lion, Balearic Islands, Sardinia and Corsica). The samples were collected from an $11 \mathrm{~m}$ sailing ship using a "Manta Trawl" surface net tow. The Manta Trawl was placed on the windward side of the ship at a distance of 2.5 meters of the hull to avoid any wake effect of the ship. The net had a mesh size of $0.33 \mathrm{~mm}$, and the size of the inlet flow rectangular opening was $0.6 \mathrm{~m} * 0.15 \mathrm{~m}$. The samples have been collected at a target speed of $1.4 \mathrm{~m} / \mathrm{s}$ in wind conditions between 0 and $10.3 \mathrm{~m} / \mathrm{s}$. The duration of the trawl ranged from 45 to 90 minutes and the distance covered during such trawl ranged from 3'000 and 9'500 m. The average wind speed for all collected samples was $3.7 \mathrm{~m} / \mathrm{s}$. The wind speed was recorded 
at a height of $14 \mathrm{~m}$, and the sea conditions were classified in 3 categories: slight (wave height $<0.5 \mathrm{~m}$ ), smooth $(0.5 \mathrm{~m}<$ wave height $<1.25 \mathrm{~m})$ and moderate $(1.25<$ wave height $<2.5 \mathrm{~m})$; only one sample was collected in moderate conditions. Samples have been stored in tube bottles in water saturated by salt at room temperature and protected from exposure to light.

\section{Analysis}

Samples were first sieved through $5 \mathrm{~mm}$ and $300 \mu \mathrm{m}$ sieves to separate mesoparticles from microparticles, and rinsed with distilled water. The resulting filtrate was placed in plastic Petri dishes, and observed through a stereo microscope. All particles were visually identified, separated from the plankton and sorted into six form categories based on that of (Shaw and Day, 1994): fragments from larger pieces, pellets (including preproduction pellets as well as smaller cosmetics microbeads), lines (fishing lines and synthetic fibers), thin films, foams and other particles (tar, glass, etc.). Once dried for $24 \mathrm{~h}$ at $60^{\circ} \mathrm{C}$, the particles of each category were counted and weighted (accuracy $0.1 \mathrm{mg}$ ). The plankton remaining after the extraction of plastic was sorted as smaller or bigger than $5 \mathrm{~mm}$ and weighted after drying.

\section{Correction due to the effect of wind mixing}

Kukulka and others (Kukulka et al., 2012) demonstrated that plastic debris is vertically distributed within the upper water column due to wind-driven mixing and that surface net tows cannot account for the total amount of plastic pieces in the upper ocean mix layer, except in low wind conditions $\left(\mathrm{u}_{10}<4 \mathrm{~m} / \mathrm{s}\right)$. They proposed a model based on net tow data combining wind speed measurement to improve the estimation of the total amount of plastic in the wind-mixed surface layer.

This model is used in this paper for slight wind conditions $\left(4 \mathrm{~m} / \mathrm{s} \leq \mathrm{u}_{10} \leq 11 \mathrm{~m} / \mathrm{s}\right)$ with the hypothesis of fully developed sea conditions. For each net tow, the wind speed was measured at the top of the mast and calculated at $10 \mathrm{~m}$ using the log profile formulae proposed by Large and Pond (Large and Pond, 1981). The significant wave height was determined using an empirical formula (Thorpe et al., 2003) as a function of wind speed. Applying Kukulka's approach, a correction factor was defined for each tow to estimate the total amount of plastic in the water column.

The average correction factor over all collected samples is 1.55, and the maximum value 11.0. For comparison, the average correction factor for the data sets of the North Atlantic evaluated by Kukulka and others is 2.5 and the maximum value is 27 (Kukulka et al., 2012). This result can be explained by the soft wind conditions 
encountered during these two expeditions (average wind speed: $3.7 \pm 1.9 \mathrm{~m} / \mathrm{s} \mathrm{SD}$ ).

\section{Results and discussion}

All 41 net tows contained detectable levels of micro and mesoplastic particles. The highest concentration of measured microplastic exceeded $420^{\prime} 000$ parts $/ \mathrm{km}^{2}$ and $216^{\prime} 000 \mathrm{mg} / \mathrm{km}^{2}$, while the lowest was inferior to $10^{\prime} 000$ parts $/ \mathrm{km}^{2}$ and $8^{\prime} 000 \mathrm{mg} / \mathrm{km}^{2}$. As presented in Fig. 1, the average values of all collected samples were $130^{\prime} 000$ parts $/ \mathrm{km}^{2}$ and $57^{\prime} 000 \mathrm{mg} / \mathrm{km}^{2}$. A classification of plastics according to their shape and appearance revealed that fragments are largely predominant (73\% in number, $72 \%$ in mass), followed by thin films (14\% in number, $8 \%$ in mass), foams (5\% in number, $7 \%$ in mass), lines (2\% in number, $2 \%$ in mass) and pellets (1\% in number, $4 \%$ in mass).

In number, the average concentration of plastic particles is similar to the one presented by Collignon and others in the Mediterranean Sea (Collignon et al., 2012) (Table 1). However, we found lighter particles and therefore a lower average mass concentration. Different sampling zones (wider in the present study), types of plastic found, wind conditions or analysis methodologies (full visual sampling allowing very small particles detection in our case versus a preliminary separation by sedimentation in their study) can explain this discrepancy.

Comparing our data with other results obtained in the North Pacific gyre reveals that the concentration is smaller but of the same order of magnitude (Law et al., 2014 ; Cózar et al., 2014). Moreover, the composition of the different plastics types found by Moore and others in the same region (Moore et al., 2001) is very similar to our findings in the Mediterranean Sea (Table 2). The concentration is also of the same order of magnitude as the highest average value observed in the North Atlantic gyre (about 100'000 particles $/ \mathrm{km}^{2}, 27^{\circ} \mathrm{N} 55^{\circ} \mathrm{W}$ (Law et al., 2010) but much higher than the average value in the North Atlantic near $30^{\circ} \mathrm{N}\left(20^{\prime} 000\right.$ particles $/ \mathrm{km}^{2}, 29^{\circ}$ to $31^{\circ} \mathrm{N}$ (Law et al., 2010)).

We also measured an average ratio of microplastics to plankton of almost 0.5, with a maximum ratio of 6.1 (Fig. 1). This ratio must be considered cautiously for several reasons: first, the sea conditions, time of day, regional currents and seasonal variations influence the abundance of plankton. Secondly, this ratio does not provide direct support of plankton feeders ingesting plastics, as this is also dependent of the shape, colour, size and abundance 
of their natural preys (Shaw and Day, 1994). Nevertheless, high concentration of microplastics increases the probability of misinterpretations. Indeed, Boerger and others demonstrated the presence of plastic particles in the stomach of planktivorous fish in the North Pacific Central Gyre (Boerger et al., 2010). It should be noted that even if ingestion happens, the translocation effect to tissues is probably limited. Indeed, a recent research demonstrated that microparticles ingested by plankton feeders are excreted after a reduced time (Cole et al., 2013).

Concerning mesoplastics, the highest concentration that was observed was superior to 21 ' 000 parts $/ \mathrm{km}^{2}$ and $500^{\prime} 000 \mathrm{mg} / \mathrm{km}^{2}$, while the lowest was inferior to $310 \mathrm{parts} / \mathrm{km}^{2}$ and $3^{\prime} 500 \mathrm{mg} / \mathrm{km}^{2}$. The average values for all collected samples was $5^{\prime} 700$ parts $/ \mathrm{km}^{2}$ and $125^{\prime} 000 \mathrm{mg} / \mathrm{km}^{2}$, mainly composed of fragments (33\% in number, $69 \%$ in mass), films (45\% in number, $21 \%$ in mass) and lines (20\% in number and $4 \%$ in mass) (Fig. 1). It can be noticed here that these proportions (in mass $/ \mathrm{km}^{2}$ ) are very similar to those observed with microparticles.

Interestingly, results presented in Fig. 1 reveal a higher concentration of mesoplastics in terms of mass, even if microplastics are more present in terms of number. Moreover, during results analysis, an unexpected point stood out: as shown in Fig. 2, there is a strong correlation between micro- and mesoplastic concentrations, with an overall correlation coefficient of 0.77 for smooth and slight wind conditions. This result, supported by similar mass composition, suggests that microplastic concentrations could be extrapolated from measured mesoplastic concentrations. If confirmed by additional observations, this could greatly simplify future analysis. These observations do not necessarily imply that all microplastics originate from mesoplastics fragmentation: pellets, cosmetic beads and some synthetic fibers are sources of primary microplastics (Browne et al., 2011; Leslie, 2014). Also, it can be supposed that not all mesoplastics will be fragmented in pieces the size of microplastics, some will directly fragment to even lower dimensions. Furthermore, the sampling zone cannot be considered as a closed system and a fraction of microplastics could sink to the seabed (Woodall et al., 2014).

Different external conditions that could affect local microplastic concentrations were further investigated. Although all samples showing more than $300^{\prime} 000$ particles $/ \mathrm{km}^{2}$ are close to the coast, no particular zone seems to stand out in our sampling region (Fig. 3). The microplastic concentrations are variable, and not correlated to the seasonal currents nor to the population densities when map layers are overlaid. Nevertheless, average microplastic concentrations vary significantly depending on the wind and sea conditions, ranging from more 
than $1500^{\prime} 000$ particles $/ \mathrm{km}^{2}$ in smooth conditions $\left(\mathrm{u}_{10} \leq 4 \mathrm{~m} / \mathrm{s}\right)$ to less than 100 '000 particles $/ \mathrm{km}^{2}$ in slight conditions $\left(4 \mathrm{~m} / \mathrm{s}<\mathrm{u}_{10} \leq 10 \mathrm{~m} / \mathrm{s}\right)$. This highlights the relevance of applying a correction factor taking into account the effect of wind stress on the vertical distribution of the microplastics in the water column, as described in the methodology. After applying the wind stress correction model, the average concentration in slight sea conditions reaches $180^{\prime} 000$ particles $/ \mathrm{km}^{2}$, much closer to that of smooth sea conditions. Fig. 3 also shows a homogeneous spatial distribution of the corrected concentrations, as compared to the non-corrected ones.

The effect of wind conditions on different plastic types in the water column must still be studied in more detail, but it probably also plays a role in the plastic's concentration and distribution. Overall, the vertical mixing phenomena needs to be further investigated, and systematically taken into account when assessing plastic pollution in order to be able to compare the concentrations regardless of the weather conditions. Recently, similar approaches have been used to evaluate the plastic abundance over the full water column (Cózar et al., 2014; Eriksen et al., 2014; Law et al., 2014).

In order to assess a possible regional influence in the proportion of the different microplastics types, these proportions for each sample have been superimposed on a map (Fig. 4). The results again show a quite homogenous distribution with an overall predominance of the fragment fraction, even if the thin films fraction can reach more than a third of the total count for some samples. For two samples, located between Corsica and the continental coast, foams also count for more than half of the total. These samples have been collected sequentially, thus, a regional bias cannot be clearly demonstrated due to the limitation of the number of samples, and their relative distance. This limitation also hinders any interpolation of the concentrations, which would require many more sampling points.

We also investigated the temporal variability between the two collection campaigns (2011 and 2012). It appears that although the average mass concentrations were almost similar (53'273 vs 59'979 mg/km²), the concentration in number was two times higher in 2012 (86’476 vs 157'858 particles/km²). This result first reflects the high variability in the composition of each sample in term of number and size of particles. Importantly, the wind conditions were stronger during our samplings in 2011 than in $2012(4.1 \mathrm{vs} 3.1 \mathrm{~m} / \mathrm{s}$ on average), thus reducing the number of collected surface particles. This difference in number was reduced when 
comparing the corrected values (137'694 in 2011 vs $181^{\prime} 520$ particles $/ \mathrm{km}^{2}$ in 2012). Finally, geographical sampling zones were slightly different (see Fig. 3). For these reasons, it would be difficult to invoke a temporal justification to support these differences. Note that strong variations in measured concentrations from one year to another have already been reported in the North Atlantic by others (Law et al., 2010).

\section{Conclusion}

This study proposes an evaluation of surface plastic pollution in an area between the Gulf of Lion, the Balearic Islands, Sardinia and Corsica based on 41 samples collected during the summers of 2011 and 2012. It reveals that micro- and mesoplastic debris are widely and uniformly distributed in the Western Mediterranean Sea with respective concentrations of $1300^{\prime} 000 \mathrm{parts} / \mathrm{km}^{2}$ and $5^{\prime} 700 \mathrm{parts} / \mathrm{km}^{2}$. A typological analysis was performed indicating the predominant presence of fragments (73\%) and thin films (14\%), but also lines, foams and pellets. Moreover, a comparison with the abundance of plankton in our samples revealed an average ratio plastic/plankton reaching a value of 0.5 .

These results confirm the findings proposed by Collignon and others (Collignon et al., 2012), indicating that the plastic pollution in the Mediterranean Sea is of the same order of magnitude that in subtropical gyres.

A model to take into account the effect of surface wind stress proposed by Kukulka and others has been applied (Kukulka et al., 2012). The corrected average microplastic concentration is about 170 '000 parts $/ \mathrm{km}^{2}$ in the Mediterranean Sea. A correlation between microplastic and mesoplastic concentrations has also been identified. Furthermore, in term of mass, composition of micro- and mesoparticles is highly similar. These results could suggest that an average microplastic concentration could be extrapolated from mesoplastic concentration measurements.

The Mediterranean Sea is a closed sea surrounded by densely populated countries generating important quantities of waste. International plastic production and consumption continues to increase. This study proposes detailed data concerning the present state of plastic pollution in the Western Mediterranean Sea. Further researches are required to establish more precisely the level of this pollution, monitor its evolution over time, understand the plastic transport phenomena in this basin and identify the marine debris sources. 


\section{Compliance with Ethical Standards}

This study was supported by all the members and donators of Oceaneye, and in particular the Gelbert Foundation. This article does not contain any studies with human participants or animals performed by any of the authors. The authors declare that they have no conflict of interest.

\section{Acknowledgements}

The authors wish to thank the crew who participated in the samples collection, as much as all the students who contributed to develop the interest in marine plastic pollution at EPFL. We would also like to thank the volunteer members of Oceaneye who made possible the completion of this study.

\section{References}

Andrady, A.L., 2011. Microplastics in the marine environment. Mar. Pollut. Bull. 62, 1596-1605. doi:10.1016/j.marpolbul.2011.05.030

Bakir, A., Rowland, S.J., Thompson, R.C., 2014. Enhanced desorption of persistent organic pollutants from microplastics under simulated physiological conditions. Environ. Pollut. 185, 16-23. doi:10.1016/j.envpol.2013.10.007

Barnes, D.K.A., 2002. Biodiversity: Invasions by marine life on plastic debris. Nature 416, 808-809. doi:10.1038/416808a

Boerger, C.M., Lattin, G.L., Moore, S.L., Moore, C.J., 2010. Plastic ingestion by planktivorous fishes in the North Pacific Central Gyre. Mar. Pollut. Bull. 60, 2275-2278. doi:10.1016/j.marpolbul.2010.08.007

Browne, M.A., Crump, P., Niven, S.J., Teuten, E., Tonkin, A., Galloway, T., Thompson, R., 2011. Accumulation of Microplastic on Shorelines Woldwide: Sources and Sinks. Environ. Sci. Technol. 45, 9175-9179. doi:10.1021/es201811s

Browne, M.A., Dissanayake, A., Galloway, T.S., Lowe, D.M., Thompson, R.C., 2008. Ingested Microscopic Plastic Translocates to the Circulatory System of the Mussel, Mytilus edulis (L.). Environ. Sci. Technol. 42, 5026-5031. doi:10.1021/es800249a

Cole, M., Lindeque, P., Fileman, E., Halsband, C., Goodhead, R., Moger, J., Galloway, T.S., 2013. Microplastic Ingestion by Zooplankton. Environ. Sci. Technol. 47, 6646-6655. doi:10.1021/es400663f

Collignon, A., Hecq, J.-H., Galgani, F., Collard, F., Goffart, A., 2014. Annual variation in neustonic micro- and meso-plastic particles and zooplankton in the Bay of Calvi (Mediterranean-Corsica). Mar. Pollut. Bull. 79, 293-298. doi:10.1016/j.marpolbul.2013.11.023

Collignon, A., Hecq, J.-H., Glagani, F., Voisin, P., Collard, F., Goffart, A., 2012. Neustonic microplastic and zooplankton in the North Western Mediterranean Sea. Mar. Pollut. Bull. 64, 861-864. doi:10.1016/j.marpolbul.2012.01.011

Cózar, A., Echevarría, F., González-Gordillo, J.I., Irigoien, X., Úbeda, B., Hernández-León, S., Palma, Á.T., Navarro, S., García-de-Lomas, J., Ruiz, A., Fernández-de-Puelles, M.L., Duarte, C.M., 2014. Plastic debris in the open ocean. Proc. Natl. Acad. Sci. 111, 10239-10244. doi:10.1073/pnas.1314705111

Derraik, J.G.., 2002. The pollution of the marine environment by plastic debris: a review. Mar. Pollut. Bull. 44, 842-852. doi:10.1016/S0025-326X(02)00220-5 
Donohue, M.J., Boland, R.C., Sramek, C.M., Antonelis, G.A., 2001. Derelict Fishing Gear in the Northwestern Hawaiian Islands: Diving Surveys and Debris Removal in 1999 Confirm Threat to Coral Reef Ecosystems. Mar. Pollut. Bull. 42, 1301-1312. doi:10.1016/S0025-326X(01)00139-4

Doyle, M.J., Watson, W., Bowlin, N.M., Sheavly, S.B., 2011. Plastic particles in coastal pelagic ecosystems of the Northeast Pacific ocean. Mar. Environ. Res. 71, 41-52. doi:10.1016/j.marenvres.2010.10.001

Eriksen, M., Lebreton, L.C.M., Carson, H.S., Thiel, M., Moore, C.J., Borerro, J.C., Galgani, F., Ryan, P.G., Reisser, J., 2014. Plastic Pollution in the World's Oceans: More than 5 Trillion Plastic Pieces Weighing over 250,000 Tons Afloat at Sea. PLoS ONE 9, e111913. doi:10.1371/journal.pone.0111913

Fossi, M.C., Panti, C., Guerranti, C., Coppola, D., Giannetti, M., Marsili, L., Minutoli, R., 2012. Are baleen whales exposed to the threat of microplastics? A case study of the Mediterranean fin whale (Balaenoptera physalus). Mar. Pollut. Bull. 64, 2374-2379. doi:10.1016/j.marpolbul.2012.08.013

Kukulka, T., Proskurowski, G., Morét-Ferguson, S., Meyer, D.W., Law, K.L., 2012. The effect of wind mixing on the vertical distribution of buoyant plastic debris. Geophys. Res. Lett. 39, n/a-n/a. doi:10.1029/2012GL051116

Large, W.G., Pond, S., 1981. Open Ocean Momentum Flux Measurements in Moderate to Strong Winds. J. Phys. Oceanogr. 11, 324-336. doi:10.1175/1520-0485(1981)011<0324:OOMFMI>2.0.CO;2

Law, K.L., Morét-Ferguson, S.E., Goodwin, D.S., Zettler, E.R., DeForce, E., Kukulka, T., Proskurowski, G., 2014. Distribution of Surface Plastic Debris in the Eastern Pacific Ocean from an 11-Year Data Set. Environ. Sci. Technol. 48, 4732-4738. doi:10.1021/es4053076

Law, K.L., Morét-Ferguson, S., Maximenko, N.A., Proskurowski, G., Peacock, E.E., Hafner, J., Reddy, C.M., 2010. Plastic Accumulation in the North Atlantic Subtropical Gyre. Science 329, 1185-1188. doi:10.1126/science. 1192321

Leslie, H.A., 2014. Review of Microplastics in Cosmetics.

Mato, Y., Isobe, T., Takada, H., Kanehiro, H., Ohtake, C., Kaminuma, T., 2001. Plastic Resin Pellets as a Transport Medium for Toxic Chemicals in the Marine Environment. Environ. Sci. Technol. 35, 318324. doi:10.1021/es0010498

Moore, C.., Moore, S.., Leecaster, M.., Weisberg, S.., 2001. A Comparison of Plastic and Plankton in the North Pacific Central Gyre. Mar. Pollut. Bull. 42, 1297-1300. doi:10.1016/S0025-326X(01)00114-X

Morét-Ferguson, S., Law, K.L., Proskurowski, G., Murphy, E.K., Peacock, E.E., Reddy, C.M., 2010. The size, mass, and composition of plastic debris in the western North Atlantic Ocean. Mar. Pollut. Bull. 60, 1873-1878. doi:10.1016/j.marpolbul.2010.07.020

Moser, M.L., Lee, D.S., 1992. A Fourteen-Year Survey of Plastic Ingestion by Western North Atlantic Seabirds. Colon. Waterbirds 15, 83-94. doi:10.2307/1521357

Ng, K.L., Obbard, J.P., 2006. Prevalence of microplastics in Singapore's coastal marine environment. Mar. Pollut. Bull. 52, 761-767. doi:10.1016/j.marpolbul.2005.11.017

Ogata, Y., Takada, H., Mizukawa, K., Hirai, H., Iwasa, S., Endo, S., Mato, Y., Saha, M., Okuda, K., Nakashima, A., Murakami, M., Zurcher, N., Booyatumanondo, R., Zakaria, M.P., Dung, L.Q., Gordon, M., Miguez, C., Suzuki, S., Moore, C., Karapanagioti, H.K., Weerts, S., McClurg, T., Burres, E., Smith, W., Velkenburg, M.V., Lang, J.S., Lang, R.C., Laursen, D., Danner, B., Stewardson, N., Thompson, R.C., 2009. International Pellet Watch: Global monitoring of persistent organic pollutants (POPs) in coastal waters. 1. Initial phase data on PCBs, DDTs, and HCHs. Mar. Pollut. Bull. 58, 1437-1446. doi:10.1016/j.marpolbul.2009.06.014

PlasticsEurope, 2012. Plastics - the Facts 2012 An analysis of European plastics production, demand and waste data for 2011.

Shaw, D.G., Day, R.H., 1994. Colour- and form-dependent loss of plastic micro-debris from the North Pacific Ocean. Mar. Pollut. Bull. 28, 39-43. doi:10.1016/0025-326X(94)90184-8

Suaria, G., Aliani, S., 2014. Floating debris in the Mediterranean Sea. Mar. Pollut. Bull. 86, 494-504. doi:10.1016/j.marpolbul.2014.06.025

Teuten, E.L., Rowland, S.J., Galloway, T.S., Thompson, R.C., 2007. Potential for Plastics to Transport Hydrophobic Contaminants. Environ. Sci. Technol. 41, 7759-7764. doi:10.1021/es071737s 
Thompson, R.C., Olsen, Y., Mitchell, R.P., Davis, A., Rowland, S.J., John, A.W.G., McGonigle, D., Russell, A.E., 2004. Lost at Sea: Where Is All the Plastic? Science 304, 838-838. doi:10.1126/science.1094559

Thorpe, S.A., Osborn, T.R., Farmer, D.M., Vagle, S., 2003. Bubble Clouds and Langmuir Circulation: Observations and Models. J. Phys. Oceanogr. 33, 2013-2031. doi:10.1175/15200485(2003)033<2013:BCALCO>2.0.CO;2

Tomás, J., Guitart, R., Mateo, R., Raga, J.., 2002. Marine debris ingestion in loggerhead sea turtles, Caretta caretta, from the Western Mediterranean. Mar. Pollut. Bull. 44, 211-216. doi:10.1016/S0025326X(01)00236-3

Van Franeker, J.A., Blaize, C., Danielsen, J., Fairclough, K., Gollan, J., Guse, N., Hansen, P.-L., Heubeck, M., Jensen, J.-K., Le Guillou, G., Olsen, B., Olsen, K.-O., Pedersen, J., Stienen, E.W.M., Turner, D.M., 2011. Monitoring plastic ingestion by the northern fulmar Fulmarus glacialis in the North Sea. Environ. Pollut. 159, 2609-2615. doi:10.1016/j.envpol.2011.06.008

Vianello, A., Boldrin, A., Guerriero, P., Moschino, V., Rella, R., Sturaro, A., Da Ros, L., 2013. Microplastic particles in sediments of Lagoon of Venice, Italy: First observations on occurrence, spatial patterns and identification. Estuar. Coast. Shelf Sci. 130, 54-61. doi:10.1016/j.ecss.2013.03.022

Von Moos, N., Burkhardt-Holm, P., Köhler, A., 2012. Uptake and Effects of Microplastics on Cells and Tissue of the Blue Mussel Mytilus edulis L. after an Experimental Exposure. Environ. Sci. Technol. 46, 11327-11335. doi:10.1021/es302332w

Woodall, L.C., Sanchez-Vidal, A., Canals, M., Paterson, G.L.J., Coppock, R., Sleight, V., Calafat, A., Rogers, A.D., Narayanaswamy, B.E., Thompson, R.C., 2014. The deep sea is a major sink for microplastic debris. R. Soc. Open Sci. 1, 140317. doi:10.1098/rsos.140317

Yamashita, R., Tanimura, A., 2007. Floating plastic in the Kuroshio Current area, western North Pacific Ocean. Mar. Pollut. Bull. 54, 485-488. doi:10.1016/j.marpolbul.2006.11.012

\section{Table captions}

Table 1 Comparison of average concentrations of plastic particles in the Mediterranean Sea, the North Pacific and the North Atlantic

Table 2 Comparison of abundance of different microplastics types in the Mediterranean Sea, the North Pacific and the North Atlantic

\section{Figure captions}

Fig. 1 Average concentrations of micro- and mesoplastics in the Western Mediterranean Sea. Results are expressed in particle number (left, [particles $\left./ \mathrm{km}^{2}\right]$ ) and mass (right, $\left[\mathrm{mg} / \mathrm{km}^{2}\right]$ ). The relative abundance of each plastic type is detailed in the boxes. Error bars represent the Standard Error of the Mean

Fig. 2 Correlation between micro- and mesoplastic concentrations (particles $/ \mathrm{km}^{2}$ ) in the Western Mediterranean Sea in smooth and slight wind conditions. Each circle (smooth conditions) or square (slight conditions) represents one sample 
Fig. 3 Abundance and distribution of microplastics in the Western Mediterranean Sea. a: distribution of measured microplastic concentrations (particles $/ \mathrm{km}^{2}$ ). b: distribution of corrected microplastic concentrations (particles $/ \mathrm{km}^{2}$ ) according to Kukulka and others (Kukulka et al., 2012). "1" and "2" labels next to each sampling point: 2011, respectively 2012 sampling campaigns. c: average measured (white) and corrected (grey) microplastic concentrations in smooth $\left(\mathrm{u}_{10} \leq 4 \mathrm{~m} / \mathrm{s}\right)$ and slight $\left(4 \mathrm{~m} / \mathrm{s}<\mathrm{u}_{10} \leq 10 \mathrm{~m} / \mathrm{s}\right)$ conditions. Error bars represent the Standard Error of the Mean.

Fig. 4 Distribution of microplastic types in the Western Mediterranean Sea. Fractions are expressed as percentages of particles for each category 
Table1.docx.

\begin{tabular}{|c|c|c|c|}
\hline \multirow[t]{2}{*}{ Region } & \multicolumn{2}{|c|}{ Average concentrations } & \multirow[t]{2}{*}{ Source } \\
\hline & particles $/ \mathrm{km}^{2}$ & $\mathrm{mg} / \mathrm{km}^{2}$ & \\
\hline Mediterranean * & $129^{\prime} 682$ & $62 ' 211$ & this study \\
\hline Mediterranean $* *$ & 5,700 & $125^{\prime} 000$ & this study \\
\hline Mediterranean * & $116^{\prime} 000$ & $202^{\prime} 000$ & (Collignon et al., 2012) \\
\hline North Pacific gyre & $339 ' 800$ & - & (Law et al., 2014) \\
\hline North Pacific gyre & - & $300 ’ 000$ & (Cózar et al., 2014) \\
\hline North West Pacific & $174^{\prime} 000$ & - & (Yamashita and Tanimura, 2007) \\
\hline North Atlantic & $20 \prime 000$ & - & (Law et al., 2010) \\
\hline North Atlantic gyre & $100 ' 000$ & - & (Law et al., 2010) \\
\hline
\end{tabular}

Table2.docx.

\begin{tabular}{|c|c|c|c|c|c|c|c|}
\hline \multirow{2}{*}{ Region } & \multicolumn{6}{|c|}{ Average concentrations } & \multirow{2}{*}{ Source } \\
\hline & Fragments & Pellets & Lines & Films & Foams & Total & \\
\hline Mediterranean & $77 \%$ & $1 \%$ & $2 \%$ & $15 \%$ & $5 \%$ & $129^{\prime} 682$ & This study \\
\hline N. Pacific & $59 \%$ & $0 \%$ & $11 \%$ & $29 \%$ & $1 \%$ & $331 ' 809$ & (Moore et al., 2001) \\
\hline N. Atlantic $30^{\circ} \mathrm{N}$ & $91 \%$ & $5 \%$ & $2 \%$ & $1 \%$ & $1 \%$ & - & (Morét-Ferguson et al., 2010) \\
\hline
\end{tabular}




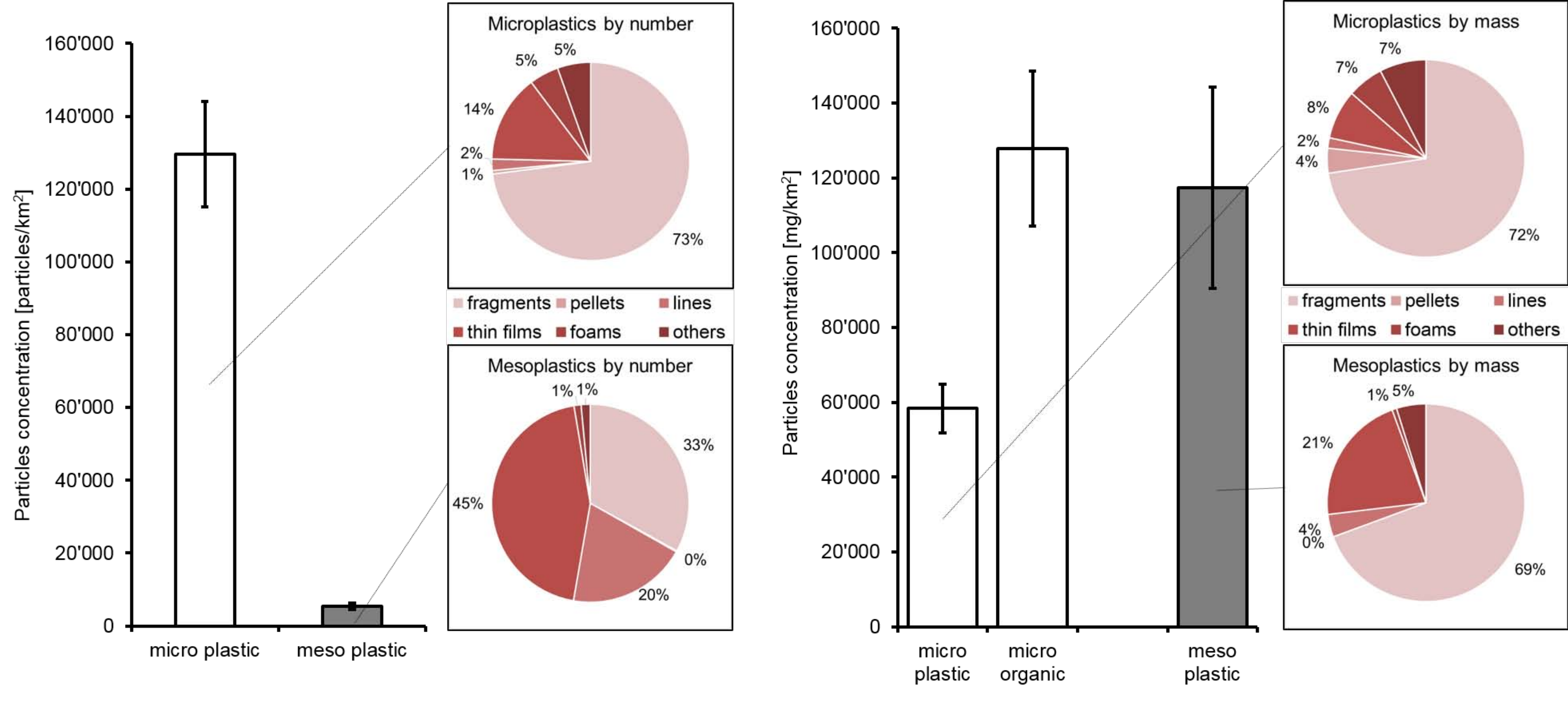


Microplastic concentrations [particles $/ \mathrm{km}^{2}$ ]

$0-40,000$

- $40^{\prime} 000-80$ '000

- $80^{\prime} 000-160 ' 000$

- $160 ' 000-320 ' 000$

- > 320'000

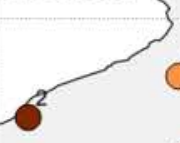

$0^{1}$
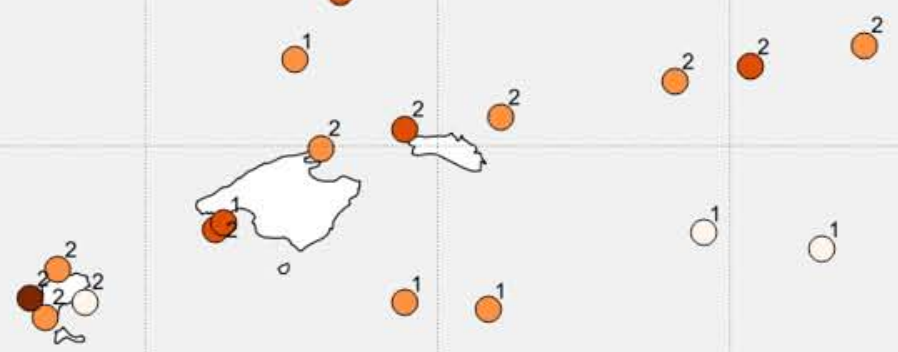

$0^{1} 0^{1}$

$2^{\circ} \mathrm{E}$

$4^{\circ} \mathrm{E}$

$6^{\circ} \mathrm{E}$

$10^{\circ} \mathrm{E}$

$8^{\circ} \mathrm{E}$

300

Corrected microplastic concentrations [particles $/ \mathrm{km}^{2}$ ]

○ $0-40,000$

- 40'000 - 80'000

- $80^{\prime} 000-1600^{\prime} 000$

- 160 '000 - 320'000

- > 320'000
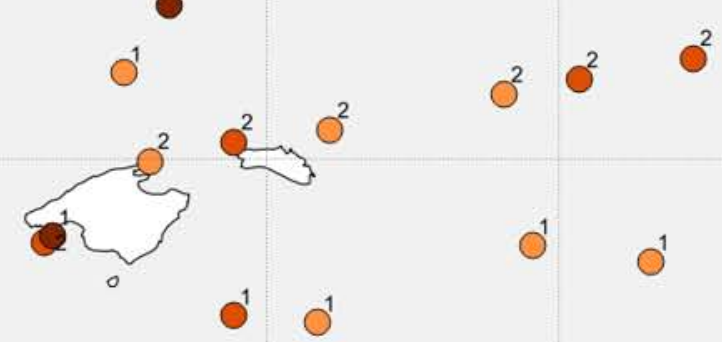

$4^{\circ} \mathrm{E}$

$6^{\circ} \mathrm{E}$

$10^{\circ} \mathrm{E}$

$8^{\circ} \mathrm{E} \stackrel{\circ}{-}$

300 
